\title{
RESPON PERTUMBUHAN BIBIT PADI PANDANWANGI (Oryza sativa L. Aromatic) TERHADAP LAMA PERENDAMAN DAN KONSENTRASI RIZOBAKTERIA PEMACU PERTUMBUHAN TANAMAN (RPPT)
}

\author{
Oleh \\ Widya Sari **) \\ Ramli **) \\ Yana Muhammad Yasin *)
}

\begin{abstract}
Abstrak
Penggunaan bakteri non patogenik yang dieksplorasi dari perakaran tanaman (rizobakteri) yang tergolong ke dalam kelompok Rizobakteri Pemacu Pertumbuhan Tanaman (RPPT) merupakan satu sumbangan bioteknologi dalam usaha peningkatan produktivitas tanaman. Penelitian ini bertujuan untuk mengetahui pengaruh konsentrasi RPPT dan lama waktu perendaman benih dengan RPPT, serta interaksinya terhadap pertumbuhan vegetatif tanaman padi Pandanwangi. Penelitian dilaksanakan bulan Maret sampai bulan Juni 2018, menggunakan Rancangan Acak Lengkap (RAL) faktorial dengan 2 faktor perlakuan yaitu lama waktu perendaman benih dan konsentrasi RPPT. Faktor I : Lama perendaman benih, dengan perlakuan : $\mathrm{T} 0=$ tanpa perendaman, $\mathrm{T} 1=4 \mathrm{jam}, \mathrm{T} 2=8 \mathrm{jam}, \mathrm{T} 3=12 \mathrm{jam}$ Faktor II, dengan perlakuan : Konsentrasi RPPT: K0 = Tanpa pemberian RPPT (kontrol), K1 = $5 \mathrm{~g}$ RPPT $/ \mathrm{L}$ air, $\mathrm{K} 2=10 \mathrm{~g}$ RPPT $/ \mathrm{L}$ air, K3 = 15g RPPT $/ \mathrm{L}$ air. Hasil penelitian menunjukkan konsentrasi RPPT dan lama perendaman benih tidak berpengaruh nyata terhadap jumlah benih berkecambah, tinggi bibit, panjang akar dan berat basah bibit padi Pandanwangi, tetapi terjadi interaksi nyata antara konsentrasi RPPT dan lama perendaman benih terhadap jumlah benih berkecambah yaitu K1 (5g/L RPPT) dengan T1 (4 jam), serta K1 (5g/L), K2 (10g/L) dengan (T0). Konsentrasi RPPT dan lama perendaman benih berinteraksi nyata pada tinggi bibit 2 mss yaitu K1 (5g/L) dengan T1 (4 jam), serta K1 (5g) dan K2 (10g) dengan (T0). Interaksi nyata juga terjadi pada 4 mss, yaitu T3 (8jam) dan T4 (12 jam)dengan K1(5g/L), K2 $(10 \mathrm{~g} / \mathrm{L})$, dan $\mathrm{K} 3(15 \mathrm{~g} / \mathrm{L})$. Tidak terdapat interaksi nyata antara konsentrasi RPPT dan lama perendaman benih terhadap panjang akar dan berat basah bibit padi Pandanwangi. Perlakuan konsentrasi dan lama perendaman benih dengan RPPT harus memperhatikan jenis tanaman dan kondisi lingkungan RPPT akan diaplikasikan.
\end{abstract}

Kata kunci : Interaksi, Konsentrasi, Lama Perendaman, Pandanwangi, Rizobakteri.

\begin{abstract}
The use of non-pathogenic bacteria explored from the roots of plants (rbizobacteria) belonging to the group Plant Growth Promoting Rhizobacteria (PGPR) is a contribution of biotechnology to increase crop productivity. This study aimed to determine the effect of PGPR concentration and duration of seed soaking with PGPR, and their interaction on vegetative growth of Pandanwangi rice. Research conducted from March to June 2018, using Factorial Complete Randomized Design with 2 factors of treatment ie: Factor I: Soaking period of seed, with treatment combinations : T0 $=$ without soaking, $T 1=4$ hours, $T 2=8$ hours, T3 = 12 hours. Factor II: PGPR concentration, with treatment combinations: KO = No PGPR (control), $K 1=5 \mathrm{~g} P G P R / L$ water, $K 2=10 \mathrm{~g} P G P R / L$ water, $K 3=15 \mathrm{~g} P G P R / L$ water. The results showed that the concentration of PGPR and duration of seed soaking did not significantly affect on the number of seed germination, seed height, root length and wet weight of Pandanwangi rice seedlings, but there
\end{abstract}

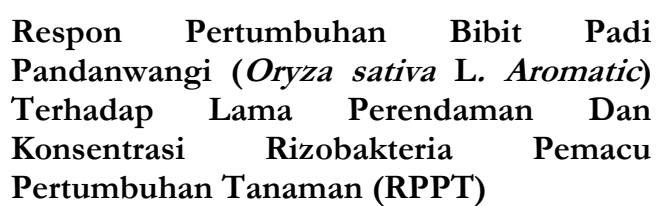

WIDYA SARI, RAMLI dan YANA MUHAMMAD YASIN

Pertumbuhan Tanaman (RPPT) 
was a significant interaction between PGPR concentration and duration of seed soaking on the number of seeds germinated, K1 (5g PGPR) with T1 (4 hours), and K1 (5g/L), K2 (10g/L) with (T0). The concentration of PGPR and duration of seed soaking interacted significantly to the seed height of K1 $(5 \mathrm{~g})$ with $T 1$ (4 hours), and $K 1$ (5g/L) and $K 2(10 \mathrm{~g} / \mathrm{L})$ with (TO) at 2 wap. The significant interaction also occurred in 4 wap, ie T3 (8h) and T4 (12h) with K1 (5g/L), K2 (10g/L), and $K 3$ (15g/L). There was no significant interaction between PGPR concentration and length of seed soaking to root length and wet weight of Pandanwangi rice seedlings. Treatment of concentration and length of seed immersion with PGPR must consider to the types of plants and environmental conditions where PGPR will be applied.

Keywords: Concentration, Duration of Seed Soaking, Interaction, Pandanwangi, Rhizobacteria.

*) Alumni Fakultas Sains Terapan UNSUR

**) Dosen Fakultas Sains Terapan UNSUR

Surel : widya.sari@unsur.ac.id

\author{
Respon Pertumbuhan Bibit Padi WIDYA SARI, RAMLI dan YANA MUHAMMAD \\ Pandanwangi (Oryza sativa L. Aromatic) \\ Terhadap Lama Perendaman Dan \\ YASIN




\section{PENDAHULUAN}

Padi merupakan bahan makanan yang menghasilkan beras, dimana bahan makanan ini merupakan bahan makanan pokok sebagian besar penduduk Indonesia. Suryana (2005), mengungkapkan bahwa 95\% penduduk Indonesia masih sangat tergantung pada beras dan beras menyumbangkan lebih dari 55\% konsumsi energi dan protein bagi rata-rata penduduk Indonesia. Padi sebagai penghasil beras merupakan bahan makanan yang mengandung gizi dan penguat yang cukup bagi tubuh manusia, karena didalamnya terkandung bahanbahan yang mudah diubah menjadi energi. Oleh karena itu padi disebut juga sebagai makanan energi (Girisonta, 1990).

Menurut KEMKES (2013), padi merupakan komoditas tanaman pangan yang perlu mendapatkan perhatian yang cukup besar. Salah satu komoditas tanaman padi yang memiliki kualitas yang unggul adalah Padi Pandanwangi. Pandanwangi merupakan padi khas Cianjur yang berasal dari padi bulu varietas lokal yang memiliki banyak keunggulan-keunggulan. Varietas unggul lokal Pandanwangi cocok ditanam di dataran sedang dengan ketinggian \pm 700 meter diatas permukaan laut. Jenis padi ini sudah lama dikenal dan dibudidayakan.

Padi Pandanwangi banyak ditanam pada musim penanaman Januari Pebruari dengan masa panen pada bulan Mei - Juni. Sedangkan pada musim penanaman Juli - Agustus diperkirakan panen bulan Nopember - Desember. Berdasarkan pengalaman petani, harga tertinggi gabah atau Padi Pandanwangi terjadi pada bulan Mei - Juni. Sebaliknya pada musim panen Nopember Desember harga padi menurun. Hal ini diduga karena pada bulan Mei - Juni merupakan bulan kering, sehingga tanaman tidak mudah rebah dan menghasilakn padi yang berisi penuh. Selain hal itu, proses pengeringan atau penjemuran lebih cepat sehingga dapat

\footnotetext{
Respon Pertumbuhan Bibit Padi Pandanwangi (Oryza sativa L. Aromatic) Terhadap Lama Perendaman Dan Konsentrasi Rizobakteria Pemacu Pertumbuhan Tanaman (RPPT)
}

menghasilkan padi (beras) yang berkualitas baik (Disperindag, 2011).

Meningkatnya pengadaan beras impor akhir-akhir ini tidak melunturkan pamor beras Cianjur. Beras Pandanwangi yang dihasilkan dari Cianjur masih banyak diminati oleh konsumen. Hal ini disebabkan karena beras Pandanwangi memiliki keunggulan yang spesifik yaitu rasa yang sangat enak, pulen, dan beraroma wangi pandan. Harga beras yang mencapai Rp 15.000 sampai dengan Rp 20.000 untuk setiap kilogramnya menyebabkan beras istimewa ini hanya menjadi konsumsi masyarakat kelas.

Fenomena di atas menunjukkan adanya peranan diferensiasi produk. Semakin berbeda suatu produk, maka semakin berbeda pula tingkat harganya. Begitu pula halnya dengan Padi Pandanwangi. Mengingat Padi Pandanwangi berbeda dengan jenis padi lainnya, dalam hal ini mempunyai keunggulan spesifik, maka tingkat harganya pun berbeda dengan jenis padi lainnya.

Berdasarkan hal tersebut perlu dilakukan berbagai upaya untuk meningkatkan produktivitas padi Pandanwangi, namun demikian teknik budidaya yang menggunakan pupuk dan pestisida kimia harus diminimalisasi, diganti dengan teknik budidaya yang lebih ramah lingkungan dan berkelanjutan. Teknologi yang sedang pesat perkembangannya saat ini adalah pemanfaatan mikroorganisme (bakteri saprofit non patogenik) yang dieksplorasi dari rizosfer tanaman (rizobakteri) yang dapat memacu pertumbuhan tanaman (Desmawati, 2006).

Penggunaan bakteri non patogenik yang dieksplorasi dari perakaran tanaman (rizobakteri) yang tergolong ke dalam kelompok Rizobakteri Pemacu Pertumbuhan Tanaman (RPPT) merupakan satu sumbangan bioteknologi dalam usaha peningkatan produktivitas tanaman. Rizobakteri merupakan suatu kelompok bakteri yang hidup secara saprofit pada daerah rizosfer atau daerah

\section{WIDYA SARI, RAMLI dan YANA MUHAMMAD YASIN}


perakaran dan beberapa jenis diantaranya dapat berperan sebagai pemacu pertumbuhan tanaman dan atau sebagai agens biokontrol terhadap penyakit sehingga mampu meningkatkan hasil tanaman pertanian (Sutariati et al., 2006 ). Informasi tentang penggunaan RPPT sebagai perlakuan benih padi Pandanwangi belum pernah didapatkan sebelumnya, sehingga perlu dilakukan penelitian untuk melihat pengaruh perlakuan konsentrasi dan lama perendaman benih dengan RPPT. Tujuan penelitian ini adalah untuk mengetahui : 1). Konsentrasi RPPT yang tepat untuk pertumbuhan vegetatif tanaman padi Pandanwangi, 2). Lama waktu perendaman benih dengan RPPT yang tepat untuk meningkatkan pertumbuhan vegetatif tanaman padi Pandanwangi, 3) Interaksi antara konsentrasi RPPT dan lama perendaman benih terhadap pertumbuhan vegetatif tanaman padi

\section{BAHAN DAN METODE}

Penelitian dilaksanakan di Screenhouse Fakultas Sains Terapan (FASTER) Universitas Suryakancana Cianjur. Waktu penelitian dilaksanakan pada bulan Januari 2018 hingga bulan Juni 2018. Alat yang digunakan dalam pelaksanaan penelitian ini adalah sebagai berikut: Ember, gelas beaker, sekop tangan, sendok, gembor, garu, penggaris, alat tulis, timbangan dan nampan. Dan bahan yang digunakan dalam penelitian ini adalah sebagai berikut: Rhizobakteria pemacu tumbuh tanaman (RPPT) yang mengandung bakteri Rhizobium sp., Bacillus polymixa dan Pseudomonas fluorescent (Gambar 1), benih padi Pandanwangi yang berasal dari koperasi Mitra Tani Parahyangan, air, label, tanah yang diambil dari pesawahan padi Pandanwangi yang bertempat di Warungkondang.

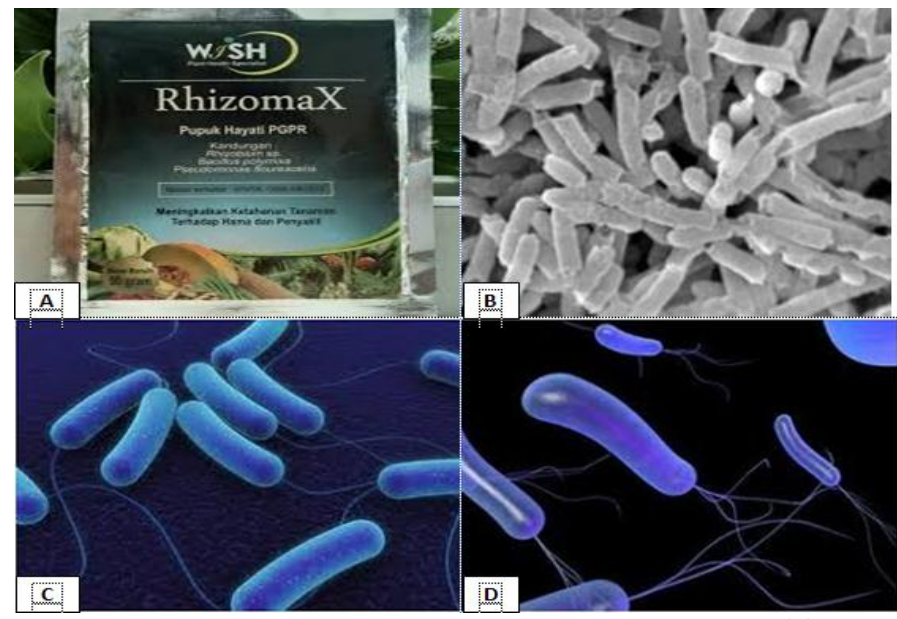

Gambar 1. Pupuk hayati yang mengandung Rhizobakteri Pemacu Pertumbuhan Tanaman(A), Rhizobium sp. (B), Bacillus polymixa (C), Pseudomonas fluorescent (D).

Rancangan penelitian yang digunakan dalam adalah Rancangan Acak Lengkap (RAL) Faktorial yang terdiri dari 2 faktor perlakuan yaitu lama waktu perendaman benih dan konsentrasi RPPT. Masing faktor terdiri dari 4 taraf perlakuan dengan 3 ulangan. Setiap unit perlakuan terdiri dari 10 tanaman, sehingga total tanaman dalam penelitian ini sebanyak 480 tanaman (unit

Respon Pertumbuhan Bibit Padi Pandanwangi (Oryza sativa L. Aromatic) Terhadap Lama Perendaman Dan Konsentrasi Rizobakteria Pemacu Pertumbuhan Tanaman (RPPT) pengamatan). Adapun unit perlakuannya sebagai berikut :

Faktor I : Lama perendaman benih

$\mathrm{T} 0=$ tanpa perendaman, $\mathrm{T} 1=4$ jam, $\mathrm{T} 2=8 \mathrm{jam}, \mathrm{T} 3=12 \mathrm{jam}$

Faktor II : Konsentrasi RPPT

$\mathrm{K} 0=$ Tanpa pemberian RPPT (kontrol), K1 = 5g RPPT $/ \mathrm{L}$ air, K2 = 10g $\mathrm{RPPT} / \mathrm{L}$ air, K3 = 15g RPPT/L air

WIDYA SARI, RAMLI dan YANA MUHAMMAD YASIN 
Parameter Penelitian yang diamati adalah: 1. Jumlah Benih yang Berkecambah

Penghitungan Persentase Jumlah Benih Berkecambah dilakukan pada saat 1 mss. Data yang didapatkan dihitung menggunakan rumus (ISTA, 2006):

$$
\% \mathbf{D B}=\frac{\sum K N}{\sum T B} x 100 \%
$$

Keterangan :

DB : Persentase Jumlah Benih Berkecambah

$\sum \mathrm{KN}$ : Jumlah benih yang berkecambah $\sum \mathrm{TB}$ : Jumlah benih yang dikecambahkan

2. Tinggi Bibit

Pengukuran tinggi tanaman dilakukan dengan cara diukur dengan menggunakan penggaris. Tanaman diukur dari pemukaan tanah hingga pucuk tanaman yang paling atas. Pengukuran tinggi tanaman dimulai sejak 1 mss hingga 4 mss. Dengan interval 1 minggu hingga tanaman memasuki fase vegetatif (4 mss).

\section{Panjang Akar}

Pengukuran tinggi tanaman dilakukan dengan cara diukur dengan menggunakan penggaris dalam satuan (cm). Pengukuran dilakukan dari pangkal akar sampai ujung akar. Pengukuran dilakukan setelah tanaman pada fase vegetatif (4 mss) kemudian dicabut tanaman padi Pandanwangi tersebut untuk kemudian diukur panjangnya.

\section{Bobot Segar}

Bobot segar padi Pandanwangi diukur dengan menggunakan timbangan analitik (dua digit dibelakang koma) yang dilakukan pada saat padi Pandanwangi dalam fase vegetatif (4 mss) kemudian dicabut dan dibersihkan terlebih dahulu untuk kemudian ditimbang.

\section{Prosedur Penelitian}

Penelitian ini dilakukan dengan beberapa langkah tahapan, yaitu :

\section{Persiapan Media Tanam}

Media tanam yang digunakan adalah tanah yang diambil dari pesawahan padi Pandanwangi. Kemudian ditimbang dan dimasukkan kedalam ember sebanyak $2 \mathrm{~kg}$ tanah /masing-masing ember sebanyak 48 ember (unit).

\section{Persiapan Benih dan Persemaian}

Benih yang digunakan didapatkan dari koperasi pertanian yang bertempat di kecamatan Warungkondang. Benih tersebut merupakan benih yang biasa digunakan petani didaerah tersebut yang sudah hasil seleksi. Benih yang digunakan sebanyak 480 benih.

Sebelum melakukan penyemaian benih disortasi dulu untuk memisahkan benih yang hampa dan benih yang bernas. benih yang mengapung tidak dapat digunakan karena merupakan benih hampa, benih di rendam dengan RPPT selama waktu yang ditentukan, setelah perendaman dilakukan penyemaian yang di tanam pada ember yang berisikan tanah.

\section{Pemeliharaan}

Pemeliharaan yang dilakukan yaitu meliputi penyiraman, pengendalian hama dan penyakit, sanitasi dan juga melakukan pendataan.

\section{Pengujian Hipotesis / Analisis Data}

Data yang diperoleh dari hasil pengamatan penelitian diolah menggunakan komputer dengan bantuan software Minitab, SPSS dan Microsoft Excell. Kemudian setelah data diolah menggunakan software tersebut selanjutnya data dianalisis melalui tabel ANOVA/tabel sidik ragam, dengan pengujian beda nyata perlakuan menggunakan Uji Tukey pada Alpha 5\%.

\footnotetext{
Respon Pertumbuhan Bibit Padi Pandanwangi (Oryza sativa L. Aromatic) Terhadap Lama Perendaman Dan Konsentrasi Rizobakteria Pemacu Pertumbuhan Tanaman (RPPT)
}

WIDYA SARI, RAMLI dan YANA MUHAMMAD YASIN 


\section{HASIL DAN PEMBAHASAN}

\section{Jumlah Benih Padi Pandanwangi yang Berkecambah}

Perkecambahan merupakan tahap awal perkembangan suatu tumbuhan, khususnya tumbuhan berbiji. Parameter pertama pada penelitian ini adalah menghitung jumlah benih yang berkecambah setelah diberi perlakuan berbagai konsentrasi Rizobakteri Pemacu Pertumbuhan Tanaman (RPPT) dan lama waktu perendaman benih.

Pengamatan jumlah benih padi Pandanwangi dilakukan 1 minggu setelah semai (mss), rata-rata perlakuan menunjukkan jumlah benih yang berkecambah $\pm 50 \%$. Berdasarkan hasil analisis sidik ragam perlakuan kosentrasi RPPT dan lama waktu perendaman benih tidak berpengaruh nyata terhadap jumlah benih padi Pandanwangi yang berkecambah pada 1 mss. (Tabel 1). Akan tetapi terjadi interaksi nyata antara perlakuan konsentrasi RPPT dan lama perendaman benih, hal ini ditunjukkan oleh nilai Sig. interaksi konsentrasi RPPT*Lama perendaman kecil dari $\alpha$ $(0,05)$ yaitu 0,02 . Hal ini juga ditunjukkan oleh perpotongan garis pada grafik interaksi (Gambar 1).

Menurut Lakitan (1996), perlakuan lama perendaman akan memengaruhi permeabilitas membran sel dan perbedaan potensial air antara di dalam dan di luar sel. Absorbsi air oleh sel tanaman akan meningkatkan turgor dalam sel, akan terjadi pembesaran sel. Selanjutnya menurut (Sadjad, 1975) ketika biji di rendam akan terjadi proses imbibisi yaitu peroses penyerapan air kedalam rongga jaringan melalui pori-pori secara pasif, terutama karena daya serap senyawa polisakarida, seperti hemiselulosa, pati, dan selulosa. Proses ini terjadi ketika air masuk kedalam benih melalui proses imbibisi yang merupakan proses spesifik dan imbibisi air oleh benih sangat dipengaruhi oleh komposisi kimia benih, permeabilitas benih dan jumlah air yang tersedia.

Jika lama perendaman melebihi lama perendaman optimum, maka proses pertumbuhan dapat terganggu. Menurut Utomo (2006), perendaman yang terlalu lama dapat menyebabkan Anoksida (kehilangan Oksigen) sehingga membatasi proses respirasi. Respirasi merupakan suatu tahapan proses perkecambahan yang terjadi setelah proses peroses air, apabila proses respirasi terbatas maka proses perkecambahan akan berjalan lambat.

Gambar 3. memperlihatkan terjadinya peningkatan jumlah benih berkecambah pada konsentrasi $5 \mathrm{~g} / \mathrm{L}$ RPPT (K1) dengan lama perendaman 4 jam (T1), juga terjadi peningkatan jumlah benih berkecambah pada konsentrasi $5 \mathrm{~g} / \mathrm{L} \quad$ (K1) dan 10g/L (K2) tanpa perlakuan perendaman benih (T0). Grafik tersebut menunjukkan semakin tinggi konsentrasi RPPT dan semakin lama perendaman akan menurunkan nilai jumlah benih berkecambah.
Respon Pertumbuhan Bibit Padi Pandanwangi (Oryza sativa L. Aromatic) Terhadap Lama Perendaman Dan Konsentrasi Rizobakteria Pemacu Pertumbuhan Tanaman (RPPT)

\author{
WIDYA SARI, RAMLI dan YANA MUHAMMAD \\ YASIN
}


Tabel 1. Jumlah benih padi Pandanwangi yang berkecambah.

\begin{tabular}{lc}
\hline Konsentrasi RPPT & Jumlah Benih Berkecambah (\%) \\
\hline $0 \mathrm{~g} / \mathrm{L}(\mathrm{K} 0)$ & $49 \mathrm{a}$ \\
$5 \mathrm{~g} / \mathrm{L}(\mathrm{K} 1)$ & $60 \mathrm{a}$ \\
$10 \mathrm{~g} / \mathrm{L}(\mathrm{K} 2)$ & $59 \mathrm{a}$ \\
$15 \mathrm{~g} / \mathrm{L}(\mathrm{K} 3)$ & $51 \mathrm{a}$ \\
\hline Lama perendaman & $59 \mathrm{a}$ \\
\hline 0 jam (T0) & $52 \mathrm{a}$ \\
4 jam (T1) & $49 \mathrm{a}$ \\
8 jam (T2) & $59 \mathrm{a}$ \\
12 jam (T3) & $*$
\end{tabular}

$\overline{\text { Angka pada lajur yang sama di ikuti oleh huruf yang sama tidak berbeda nyata menurut uji Tukey pada }}$ taraf $5 \%$.

\section{Estimated Marginal Means of jumlah kecambah}
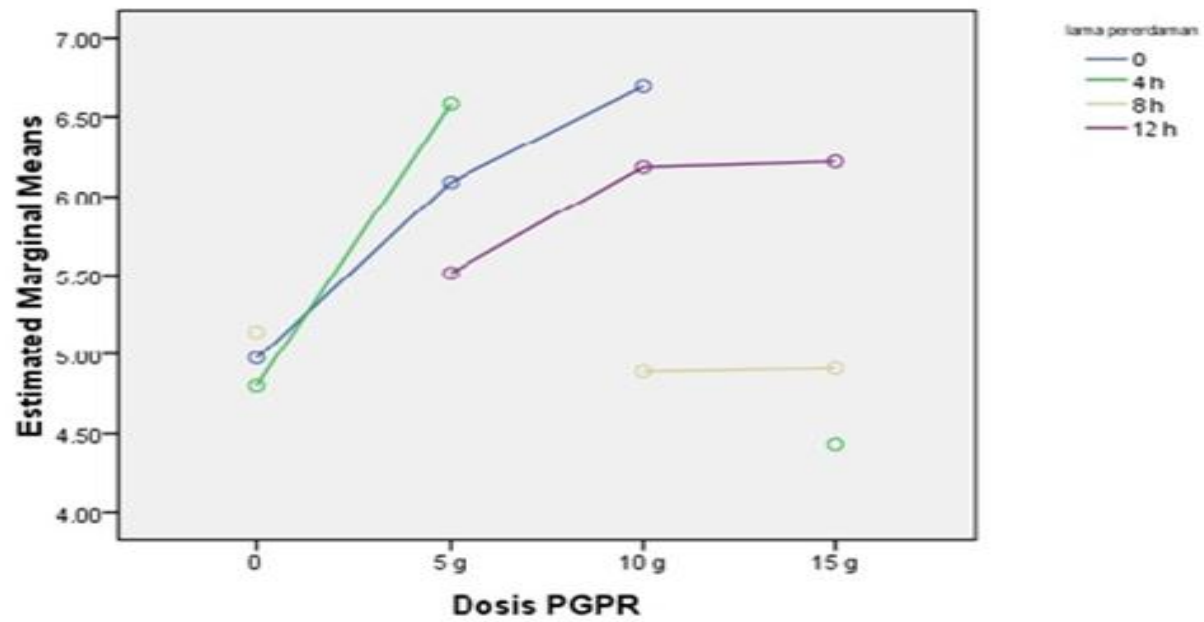

Non-əstimable means are not plotted

Gambar 2. Grafik interaksi konsentrasi RPPT dan lama perendaman benih terhadap jumlah benih Padi Pandanwangi yang berkecambah.

\section{Tinggi Bibit Padi Pandanwangi}

Tinggi tanaman merupakan ukuran tanaman yang sering diamati baik sebagai indikator pertumbuhan maupun sebagai parameter yang digunakan untuk mengukur pengaruh lingkungan atau perlakuan yang ditetapkan (Guritno dan Sitompul, 1995). Pengamatan tinggi tanaman dilakukan dengan cara mengukur bagian tanaman di atas permukaan media tanam sampai ujung daun tertinggi.

Parameter ke 2 yang diamati dalam penelitian ini adalah tinggi bibit padi

Respon Pertumbuhan Bibit Padi Pandanwangi (Oryza sativa L. Aromatic) Terhadap Lama Perendaman Dan Konsentrasi Rizobakteria Pemacu Pertumbuhan Tanaman (RPPT)
Pandanwangi. Pengukuran tinggi bibit diukur mulai 2 mss. Hasil analisis sidik ragam terhadap semua kombinasi perlakuan menunjukkan bahwa perlakuan penggunaan RPPT dan lama perendaman benih tidak berpengaruh nyata terhadap tinggi bibit Padi Pandanwangi. Akan tetapi terjadi interaksi nyata antara perlakuan konsentrasi RPPT dan lama perendaman (Tabel 2.), ditunjukkan oleh nilai Sig. interaksi konsentrasi RPPT*Lama perendaman kecil dari $\alpha$ $(0,05)$ yaitu 0,018 . Perpotongan garis pada

WIDYA SARI, RAMLI dan YANA MUHAMMAD YASIN 
grafik interaksi menunjukkan terjadi interaksi antara kedua faktor perlakuan terhadap tinggi tanaman pada pengamatan pertama 2 mss.

Tabel 2. Pengamatan Tinggi Bibit Padi Pandanwangi (2 mss).

\begin{tabular}{lccc}
\hline Konsentrasi & & Tinggi Bibit Padi Pandanwangi $(\mathrm{cm})$ & \\
RPPT & $2 \mathrm{mss}$ & $3 \mathrm{mss}$ & $4 \mathrm{mss}$ \\
\hline $0 \mathrm{~g} / \mathrm{L}$ & $24.223 \mathrm{a}$ & $39.598 \mathrm{a}$ & $45.234 \mathrm{a}$ \\
$5 \mathrm{~g} / \mathrm{L}$ & $24.732 \mathrm{a}$ & $40.147 \mathrm{a}$ & $44.125 \mathrm{a}$ \\
$10 \mathrm{~g} / \mathrm{L}$ & $24.835 \mathrm{a}$ & $41.003 \mathrm{a}$ & $44.772 \mathrm{a}$ \\
$15 \mathrm{~g} / \mathrm{L}$ & $24.993 \mathrm{a}$ & $41.296 \mathrm{a}$ & $43.216 \mathrm{a}$ \\
& & & \\
\hline Lama & & & $45.036 \mathrm{a}$ \\
perendaman & & $41.349 \mathrm{a}$ & $43.727 \mathrm{a}$ \\
\hline 0 jam & $25.919 \mathrm{a}$ & $40.213 \mathrm{a}$ & $44.816 \mathrm{a}$ \\
4 jam & $24.067 \mathrm{a}$ & $41.024 . \mathrm{a}$ & \\
$8 \mathrm{jam}$ & $24.940 \mathrm{a}$ & $39.458 \mathrm{a}$ & $*$ \\
$12 \mathrm{jam}$ & $23.858 \mathrm{a}$ & & \\
& & tn & \\
\hline Interaksi & $*$ & $\mathrm{a}$ & \\
\hline
\end{tabular}

Angka $\frac{\text { Interaksi }}{\text { pada lajur yang sama di ikuti oleh huruf yang sama tidak berbeda nyata menurut uji Tukey pada taraf }} 5 \%$.

Estimated Marginal Means of Nilai tinggi tanaman 1

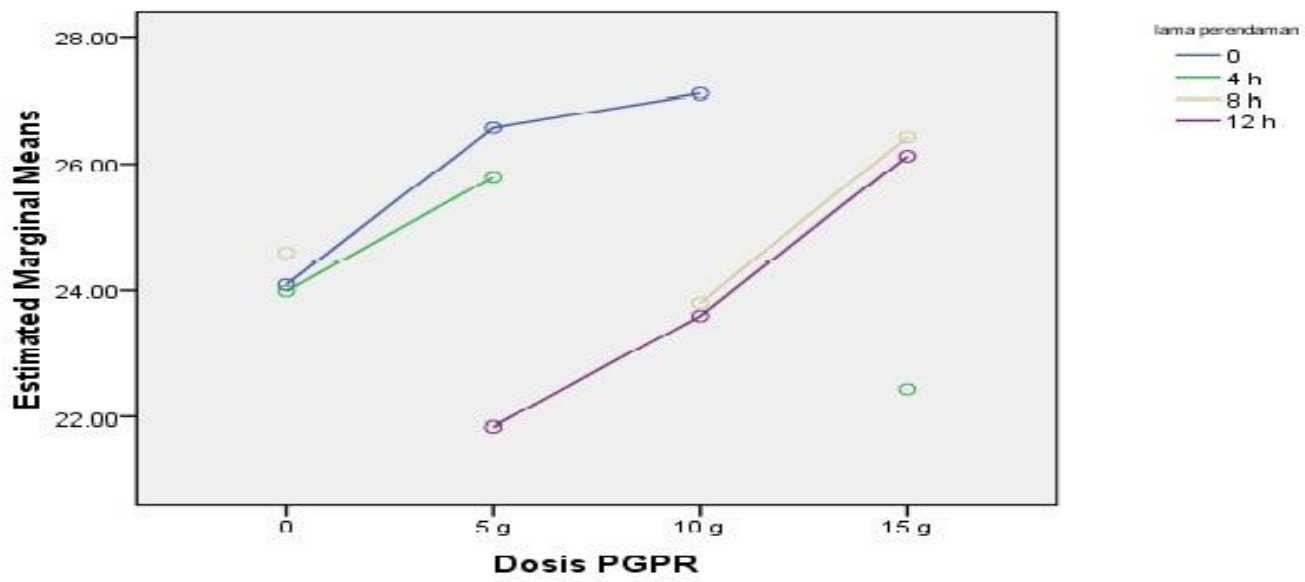

Non-estimable means are nol plotled

Gambar 3. Grafik interaksi konsentrasi RPPT dan lama perendaman benih terhadap tinggi bibit Padi Pandanwangi (2 mss).

Gambar 3. memperlihatkan terjadinya peningkatan tinggi bibit pada konsentrasi 5gr RPPT (K1) dengan lama perendaman 4 jam (T1), juga terjadi peningkatan peningkatan tinggi bibit pada konsentrasi $5 \mathrm{~g} / \mathrm{L}$ (K1) dan 10g/L (K2) tanpa perlakuan perendaman benih (T0).

Pengukuran tinggi bibit yang ke dua dilakukan pada 3 mss. Hasil sidik ragam terhadap pengamatan tinggi bibit

\footnotetext{
Respon Pertumbuhan Bibit Padi Pandanwangi (Oryza sativa L. Aromatic) Terhadap Lama Perendaman Dan Konsentrasi Rizobakteria Pemacu Pertumbuhan Tanaman (RPPT)
}

padi Pandanwangi menunjukkan tidak terdapat perbedaan yang nyata antara konsentrasi RPPT dan lama perendaman benih terhadap tinggi bibit, juga tidak terjadi interaksi antara konsentrasi dan lama perendaman terhadap tinggi bibit. Hal ini ditunjukkan oleh nilai sig. 0,853 > $\alpha 0.05$, dan tidak terdapat perpotongan garis antar konsentrasi dan lama perendaman (Gambar 4.).

\section{WIDYA SARI, RAMLI dan YANA MUHAMMAD YASIN}


Pengamatan tinggi tanaman ke empat diamati setelah bibit berumur 4 mss. Hasil analisis sidik ragam pengamatan tinggi bibit menunjukkan tidak terdapat perbedaan yang nyata antara konsentrasi dan lama perendaman, akan tetapi terjadi interaksi nyata antara konsentrasi dan lama perendaman terhadap tinggi bibit dengan nilai sig. $0,002<\alpha 0.05$ Interaksi juga ditunjukkan oleh adanya potongan garis antar konsentrasi dan lama perendaman (Gambar 5).

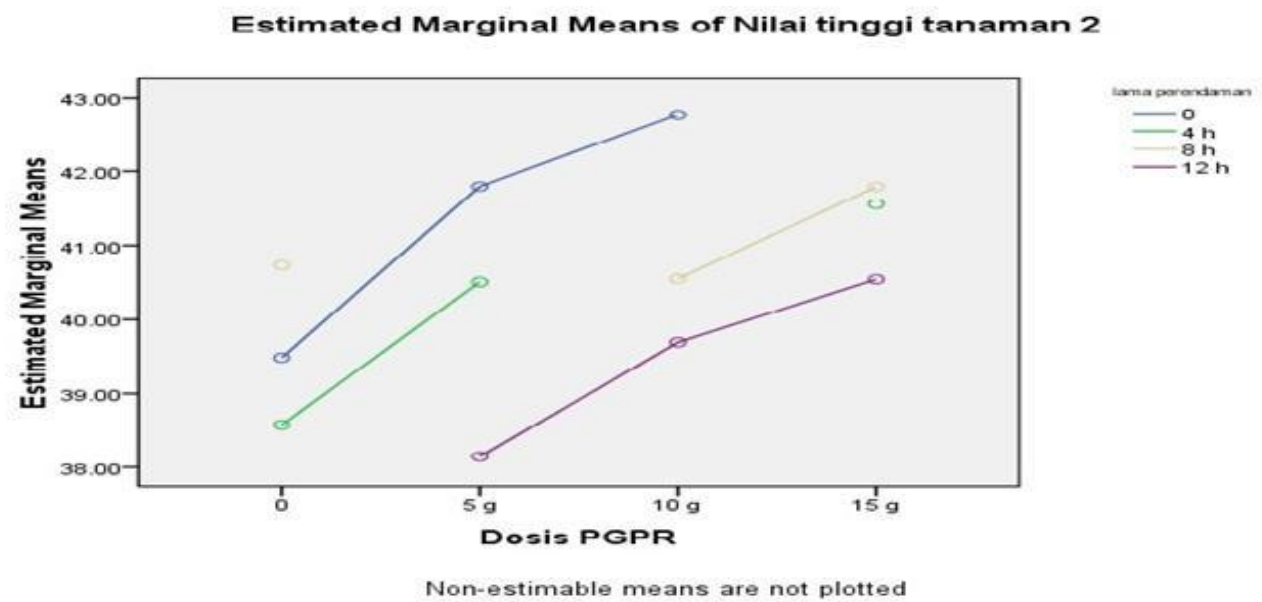

Gambar 4. Grafik interaksi konsentrasi RPPT dan lama perendaman benih terhadap tinggi bibit Padi Pandanwangi (3 mss).

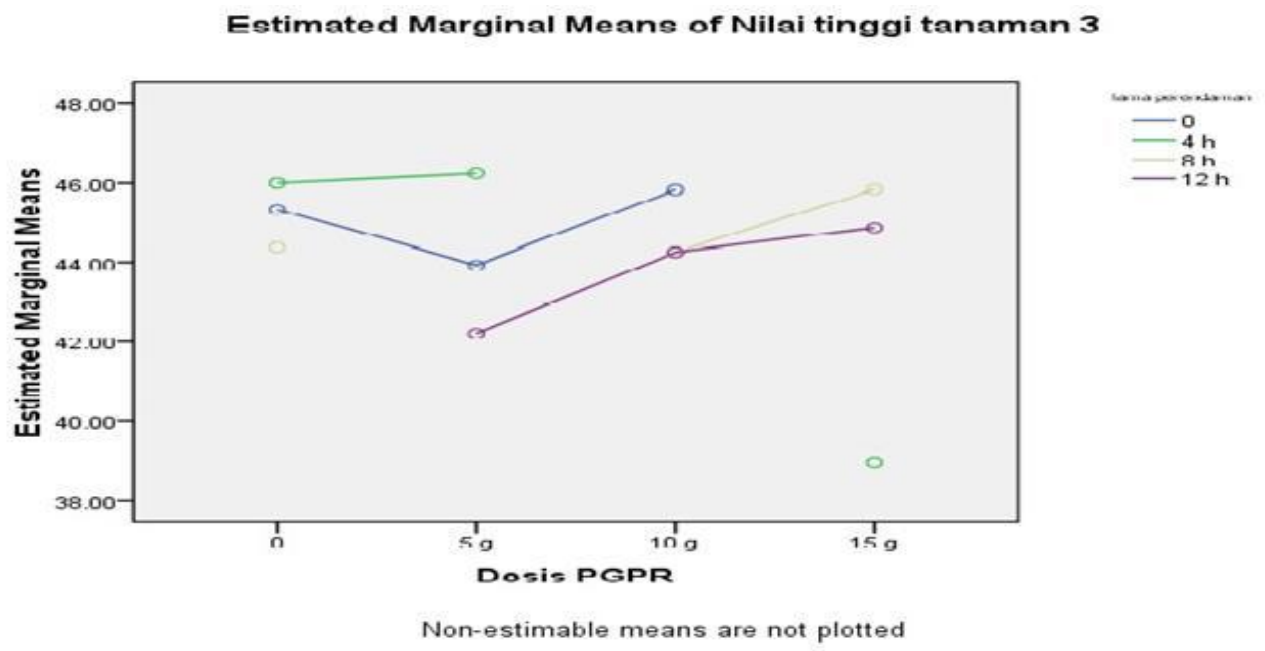

Gambar 5. Grafik interaksi konsentrasi RPPT dan lama perendaman benih terhadap tinggi bibit Padi Pandanwangi (4 mss).

Gambar 5. menunjukkan lama perendaman 8 jam (T3) dan 12 jam (T4) dengan peningkatan konsentrasi RPPT dari $5 \mathrm{~g} / \mathrm{L}, 10 \mathrm{~g} / \mathrm{L}$, dan $15 \mathrm{~g} / \mathrm{L}$ dapat meningkatkan pertambahan tinggi bibit
Respon
Pertumbuhan
Bibit Padi
Pandanwangi (Oryza sativa L. Aromatic)
Terhadap Lama Perendaman Dan
Konsentrasi Rizobakteria Pemacu
Pertumbuhan Tanaman (RPPT)

padi Pandanwangi. Pada penelitian ini perlakuan pemberian konsentrasi RPPT dan lama perendaman mempengaruhi pertambahan tinggi bibit padi Pandanwangi.

WIDYA SARI, RAMLI dan YANA MUHAMMAD YASIN 
Hasil penelitian yang dilakukan oleh Maunuksela (2004) didapatkan bahwa rhizobakteria kelompok Bacillus spp., Pseudomonas fluorescens dan Serratia spp, memiliki kemampuan memproduksi hormon tumbuh seperti asam indol asetat (IAA) yang dapat memacu pertumbuhan dan pertambahan tinggi tanaman.

\section{Panjang Akar Bibit Padi Pandanwangi}

Akar adalah bagian dari tumbuhan yang tumbuh ke arah bawah yaitu dalam media. Akar merupakan organ vegetatif utama yang memasok air, mineral dan bahan-bahan yang penting untuk pertumbuhan dan perkembangan tanaman. Menurut Sitompul dan Guritno (1995), peran akar dalam pertumbuhan tanaman sama pentingnya dengan tajuk, tajuk berfungsi untuk menyediakan karbohidrat melalui proses fotosintesis, maka fungsi akar adalah menyediakan unsur hara dan air yang diperlukan dalam metabolisme tanaman. Kemampuan tanaman terhadap daya serap unsur hara dapat dilihat memalui pengukuran poriferasi akar, panjang akar, berat segar akar dan berat kering akar.
Parameter ke 3 pada penelitian ini adalah pengukuran panjang akar yang dilakukan setelah pengamatan tinggi tanaman (minggu ke 4). Semua bibit padi dicabut kemudian dilakukan pengukuran akar. Penelitian ini menunjukkan konsentrasi RPPT dan lama waktu perendaman terhadap panjang akar bibit padi. Berdasarkan hasil analisis sidik ragam menunjukkan bahwa perlakuan penggunaan Rizobakteri Pemacu Pertumbuhan Tanaman (RPPT), dengan lama waktu perendaman benih tidak berpengaruh nyata terhadap panjang akar bibit padi Pandanwangi (Tabel 3.). Antara perlakuan konsentrasi RPPT dan lama perendaman tidak terjadi interaksi karena tidak adanya potongan garis, perpotongan garis dengan nilai sig. 0,777 $>\propto 0.05$.

Tabel 3. Pengamatan Panjang Akar Bibit Padi Pandanwangi.

\begin{tabular}{lc}
\hline Konsentrasi RPPT & Panjang akar \\
\hline $0 \mathrm{~g} / \mathrm{L}$ & $14,638 \mathrm{a}$ \\
$5 \mathrm{~g} / \mathrm{L}$ & $15,191 \mathrm{a}$ \\
$10 \mathrm{~g} / \mathrm{L}$ & $15,406 \mathrm{a}$ \\
$15 \mathrm{~g} / \mathrm{L}$ & $14,317 \mathrm{a}$
\end{tabular}

\begin{tabular}{ll}
\hline Lama perendaman & \\
\hline 0 jam & $14.957 \mathrm{a}$ \\
4 jam & $14,656 \mathrm{a}$ \\
8 jam & $14,417 \mathrm{a}$ \\
12 jam & $15,522 \mathrm{a}$
\end{tabular}

Interaksi
taraf $5 \%$.

Respon Pertumbuhan Bibit Padi
Pandanwangi (Oryza sativa L. Aromatic)
Terhadap Lama Perendaman Dan
Konsentrasi Rizobakteria Pemacu
Pertumbuhan Tanaman (RPPT)

WIDYA SARI, RAMLI dan YANA MUHAMMAD YASIN 
Estimated Marginal Means of Panjang akar
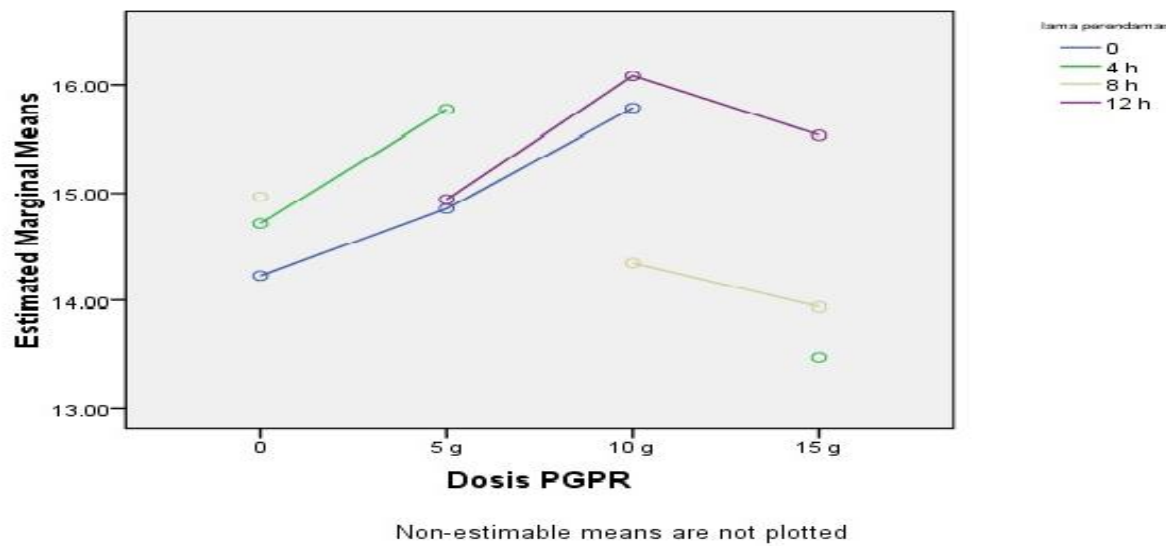

Gambar 6. Grafik interaksi konsentrasi RPPT dan lama perendaman benih terhadap panjang akar bibit Padi Pandanwangi (4 mss).

Gambar 6. menunjukkan tidak terdapat interaksi antara perlakuan konsentrasi RPPT dan lama perendaman benih terhadap panjang akar. Hal ini bisa di sebabkan oleh faktor media tanaman yang digunakan. Media tanam berkaitan erat dengan daya dukungnya terhadap pertumbuhan akar sebagai organ yang berfungsi untuk menyerap air dan unsur hara. Hal ini sesuai pernyataan Benyamin (2000), bahwa sistem perakaran dapat dipengaruhi oleh kondisi tanah atau media tumbuh tanaman. Pada penelitian ini media tanam yang di gunakan adalah tanah yang berasal lahan sawah padi Pandanwangi yang di masukan ke dalam ember sebagai unit pengamatan, hal ini diduga sangat berpengaruh karena airasi dan drainase yang kurang untuk media, sehingga sirkulasi oksigen di daerah perakaran menjadi rendah. Kondisi tersebut menyebabkan akar tidak bisa berkembang dengan sempurna. Hal ini sesuai penyataan Herdiyanti (2015), bahwasanya pergerakan air dan hara tanaman terjadi lewat ruang pori dimana terjadi sirkulasi O2 dan $\mathrm{CO} 2$, sehingga berpengaruh terhadap perkembangan akar tanaman.

Berat segar menunjukkan kandungan air dan nutrisi pada jaringan tanaman, penimbangan berat segar bertujuan untuk mengetahui serapan air dan tutrisi yang terkandung dalam

\footnotetext{
Respon Pertumbuhan Bibit Padi Pandanwangi (Oryza sativa L. Aromatic) Terhadap Lama Perendaman Dan Konsentrasi Rizobakteria Pemacu Pertumbuhan Tanaman (RPPT)
}

tanaman, hal ini merupakan ukuran yang digunakan untuk mempelajari pertumbuhan tanaman (Sitompul dan Guritno, 1995).

\section{Pengamatan Berat Basah Bibit Padi Pandanwangi}

Pertambahan massa sering ditentukan dengan memanen seluruh bagian tanaman dan menimbangnya dengan keadaan segar dan bersih sebelum terjadinya penguapan dari tanaman (Salisbury dan Ross, 1995). Bagian tanaman seperti akar, daun, dan batang dibersihkan dari tanah dan kotoran lain. Berat basah tanaman yaitu gabungan berat daun akar dan batang. Pengukuran berat basah dilakukan sesudah melakukan pengamatan pengukuran panjang akar, dengan menggunakan timbangan analitik digital.

\begin{tabular}{lcr}
\multicolumn{3}{c}{ Berdasarkan hasil analisis sidik } \\
ragam data berat basah bibit \\
menunjukkan & bahwa & perlakuan \\
penggunaan & Bakteri & Pemacu
\end{tabular}
Pertumbuhan Tanaman (RPPT), dengan lama waktu perendaman tidak berpengaruh nyata terhadap Berat basah bibit Padi Pandanwangi pada $4 \mathrm{mss}$ (Tabel 4). Antara perlakuan konsentrasi RPPT dan lama perendaman tidak terjadi interaksi karena tidak adanya perpotongan garis dengan nilai sig. $0,175>\propto 0.05$

WIDYA SARI, RAMLI dan YANA MUHAMMAD YASIN 
Tabel 4. Pengamatan Berat Basah Bibit Padi Pandanwangi.

\begin{tabular}{lc}
\hline \multicolumn{1}{c}{ Konsentrasi RPPT } & Berat Basah \\
\hline $0 \mathrm{~g} / \mathrm{L}$ & $0,975 \mathrm{a}$ \\
$5 \mathrm{~g} / \mathrm{L}$ & $0,945 \mathrm{a}$ \\
$10 \mathrm{~g} / \mathrm{L}$ & $5,166 \mathrm{a}$ \\
$15 \mathrm{~g} / \mathrm{L}$ & $1,254 \mathrm{a}$
\end{tabular}

\begin{tabular}{ll}
\hline Lama perendaman & \\
\hline 0 jam & $0,949 \mathrm{a}$ \\
4 jam & $0,983 \mathrm{a}$ \\
8 jam & $1,231 \mathrm{a}$ \\
12 jam & $5,177 \mathrm{a}$ \\
\hline
\end{tabular}

Interaksi
Angka pada lajur yang sama di ikuti oleh huruf yang sama tidak berbeda nyata menurut uji Tukey pada
taraf $5 \%$.

Perlakuan konsentrasi RPPT dan lama perendaman tidak berpengaruh nyata terhadap bobot segar bibit padi Pandanwangi, akan tetapi peningkatan konsentrasi RPPT dan semakin lama perendaman benih menyebabkan terjadinya penurunan berat basah (BB) bibit. Hal ini terjadi karena konsentrasi RPPT yang tinggi dan perendaman benih yang lama diduga menyebabkan gangguan fisiologi bibit. Berat segar merupakan hasil pengukuran dari berat segar biomassa tanaman sebagai akumulasi bahan yang dihasilkan selama pertumbuhan.

Pada pengamatan sebelumnya diketahui bahwa semakin tinggi perlakuan konsentrasi RPPT dan semakin lama perendaman benih akan menurunkan nilai parameter pengamatan seperti daya kecambah, tinggi tanaman dan panjang akar. Hal tersebut akan mempengaruhi nilai berat segar bibit, karena berat segar merupakan akumulasi bahan yang dihasilkan selama pertumbuhan bibit padi Pandanwangi.

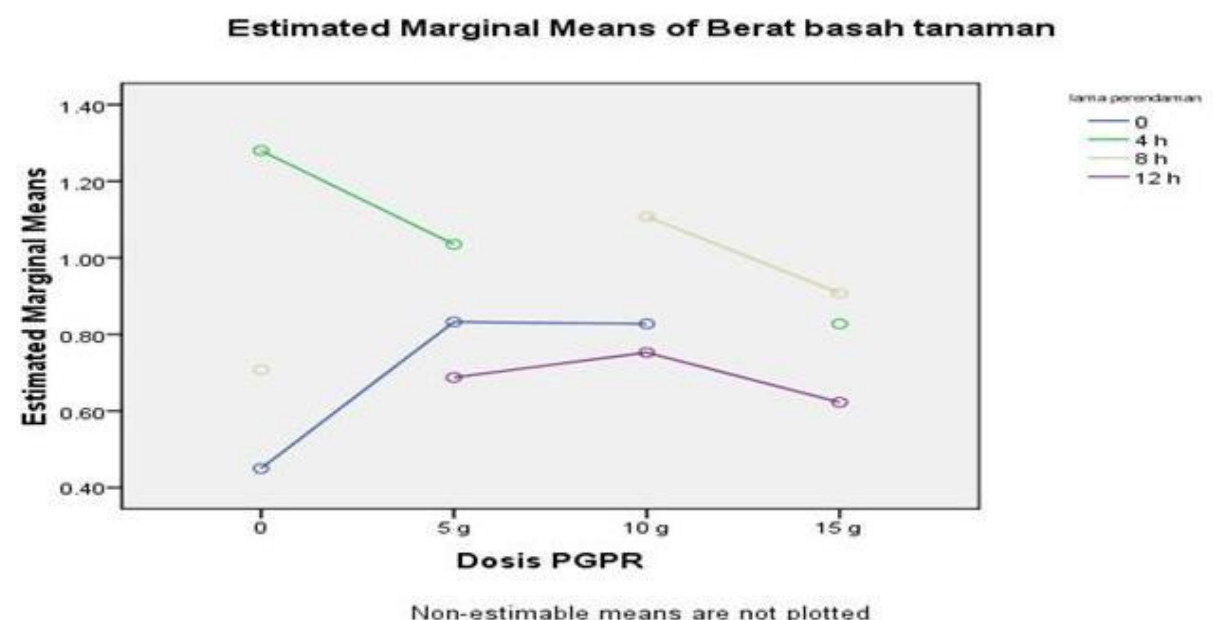

Gambar 7. Grafik interaksi konsentrasi RPPT dan lama perendaman benih terhadap berat basah Padi Pandanwangi (4 mss).

\footnotetext{
Respon Pertumbuhan Bibit Padi

Pandanwangi (Oryza sativa L. Aromatic)

Terhadap Lama Perendaman Dan

Konsentrasi Rizobakteria Pemacu

Pertumbuhan Tanaman (RPPT)
}

WIDYA SARI, RAMLI dan YANA MUHAMMAD YASIN 


\begin{abstract}
Marom et al., 2017, mengemukakan penggunaan RPPT dengan konsentrasi dan waktu pemberian dari pengguna sebelumnya tidak dapat diterapkan begitu saja tanpa memperhatikan kondisi lingkungan setempat sebagai tempat dimana RPPT diberikan sehingga perlu dilakukan penelitian untuk memperoleh konsentrasi dan lama perendaman yang tepat agar semua nilai parameter pengamatan sesuai harapan.
\end{abstract}

\section{KESIMPULAN}

1. Konsentrasi RPPT tidak berpengaruh terhadap jumlah benih berkecambah, tinggi bibit, panjang akar dan berat basah bibit padi Pandanwangi

2. Lama waktu perendaman benih dengan RPPT tidak berpengaruh terhadap jumlah benih berkecambah, tinggi bibit, panjang akar dan berat basah bibit padi Pandanwangi

3. Interaksi antara konsentrasi RPPT dan lama perendaman benih berpengaruh nyata terhadap jumlah benih berkecambah yaitu konsentrasi $5 \mathrm{~g} / \mathrm{L}$ RPPT (K1) dengan lama perendaman 4 jam (T1), serta pada konsentrasi $5 \mathrm{~g} / \mathrm{L}(\mathrm{K} 1)$ dan $10 \mathrm{~g} / \mathrm{L}(\mathrm{K} 2)$ tanpa perlakuan perendaman benih (T0). Interaksi antara konsentrasi RPPT dan lama perendaman benih berpengaruh pada tinggi bibit 2 mss yaitu konsentrasi 5g/L RPPT (K1) dengan lama perendaman 4 jam (T1), dan konsentrasi 5g/L (K1) dan 10g/L (K2) dengan tanpa perlakuan perendaman benih (T0). Interaksi nyata juga terjadi pada 4 mss, yaitu lama perendaman 8 jam (T3) dan 12 jam (T4) dengan konsentrasi RPPT $5 \mathrm{~g} / \mathrm{L}, 10 \mathrm{~g} / \mathrm{L}$ dan $15 \mathrm{~g} / \mathrm{L}$. Tidak terdapat interaksi nyata antara konsentrasi RPPT dan lama perendaman benih terhadap panjang akar dan berat basah bibit padi Pandanwangi

\footnotetext{
Respon Pertumbuhan Bibit Padi Pandanwangi (Oryza sativa L. Aromatic) Terhadap Lama Perendaman Dan Konsentrasi Rizobakteria Pemacu Pertumbuhan Tanaman (RPPT)
}

\section{DAFTAR PUSTAKA}

Benyamin, B.D. 2000., P. Roja, MR. Heble, MS. 1987. Chandra. Multiple Shoot Cultures Of Atropa Belladonna : Efect of Physicochemical Factors on Growth and Alkaloid Formation. J. Plant Nutr 129: 129-135

Desmawati. 2006. Pemanfaatan Plant Growth Promoting Rhizobacter (PGPR) Prospek Yang Menjanjikan dalam Berusaha Tani Tanaman. POPT Direktorat Perlindungan Tanaman Hortikultura dan Ditjen Hortikultura http://ditlin.hortikultura.deptan. go.id/tulisan/d esmawati.htm.

DISPERINDAG (Dinas Perindustrian dan Perdagangan). 2011. Beras Pandanwangi. Dinas Perdagangan dan Industri Kabupaten Cianjur.

Girisonta. 1990. Budidaya Tanaman Padi. Yogyakarta:Kanisius.

Hardiyanti, I. 2015. Pengaruh Temperatur Austenisasi Dan Waktu Tahan Terhadap Sifat Mekanik, Tebal Scale Dan Struktur Mikro Pada Baja Paduan Ni-Cr-Mo. Jurnal Furnace.

KEMKES (Kementrian Kesehatan). 2013. Profil Kesehatan Indonesia http://www.depkes.go.id/resour ces/download/pusdatin/profilkesehatan-indonesia/profil Kesehatan Indonesia-2013.pdf

Lakitan, B. 1996. Fisiologi Pertumbuhan dan Perkembangan Tanaman. Jakarta:Raja Grafindo Persada.

Marom, N., Rizal, F.N.U., dan Bintoro, M. 2017. Uji Efektivitas Saat Pemberian dan Konsentrasi PGPR (Plant Growth Promoting Rhizobacteria) Terhadap Produksi dan Mutu Benih Kacang Tanah (Arachis hypogaea L.). Agriprima, Journal of Applied Agricultural Sciences. 1(2):191-202. 
Maunuksela, L. 2004. Molecular And Physiological Characterization Of Rhizosphere Bacteria And Frankia In Forest Soils Devoid of Actinorhizal Plants. Dissertationes Biocentri Wikki Universitatis

Helsingiensis.http://ethesis. Helsinki.fi./julkaisnt/mat/ manuksela/ molecula.pdf.

Sadjad, S. 1975. Penyimpanan Benih Tanaman Pangan. Bahan Kuliah Latihan Pola Bertanam. LP 3IRRI. 22 hal.

Salisbury, F.B. dan Ross, C.W. 1995. Fisiologi Tumbuban, Jilid 1. Terjemahan dari Plant Physiology 4th. Edition oleh Diah R. Lukman dan Sumaryono. Bandung :ITB.

Sitompul, S.M. dan B. Guritno. 1995. Analisis Pertumbuban Tanaman. Yogyakarta:UGM-Press.

Suryana, A. 2008. Menelisik Ketahanan Pangan, Kebijakan Pangan, dan Swasembada Beras. Pengembangan Inovasi Pertanian 1(1):1-16. Badan Penelitian dan Pengembangan Pertanian. Departemen Pertanian. Bogor.

Sutariati, G.A.K. 2006. Perlakuan Benih Dengan Agens Biokontrol Untuk Pengendalian Penyakit Antraknosa dan Peningkatan Hasil Serta Mutu Benih Cabai. Disertasi .Sekolah Pascasarjana, Institut Pertanian Bogor. Bogor.163.

Utomo, Budi. 2006. Ekologi Benih. Medan:USU Repository.

\footnotetext{
Respon Pertumbuhan Bibit Padi Pandanwangi (Oryza sativa L. Aromatic) Terhadap Lama Perendaman Dan Konsentrasi Rizobakteria Pemacu Pertumbuhan Tanaman (RPPT)
}

WIDYA SARI, RAMLI dan YANA MUHAMMAD YASIN 